\title{
Prospects of Medicinal Plants Derived Nutraceuticals: A Re-emerging New Era of Medicine and Health Aid
}

\author{
Asif Mohammad1*, Mohd Imran²
}

${ }^{1}$ Department of Pharmaceutical chemistry, Himalayan Institute of Pharmacy Research, Dehradun, (Uttarakhand), India

${ }^{2}$ Department of Pharmaceutical Chemistry, Faculty of Pharmacy, Northern Border University, Rafha, Saudi

Arabia

\section{A R T I C L E I N F O}

Article history:

Submitted: 2019-04-27

Revised: 2019-06-04

Accepted: 2019-07-10

Available online:2019-09-28

Manuscript ID: PCBR-1904-1034

\section{K E Y W O R S}

Dietary supplement

Nutraceuticals

Medicine

Phytotherapy

Functional foods

Medicinal plants
GRA PH I C A L A B S T RA C T

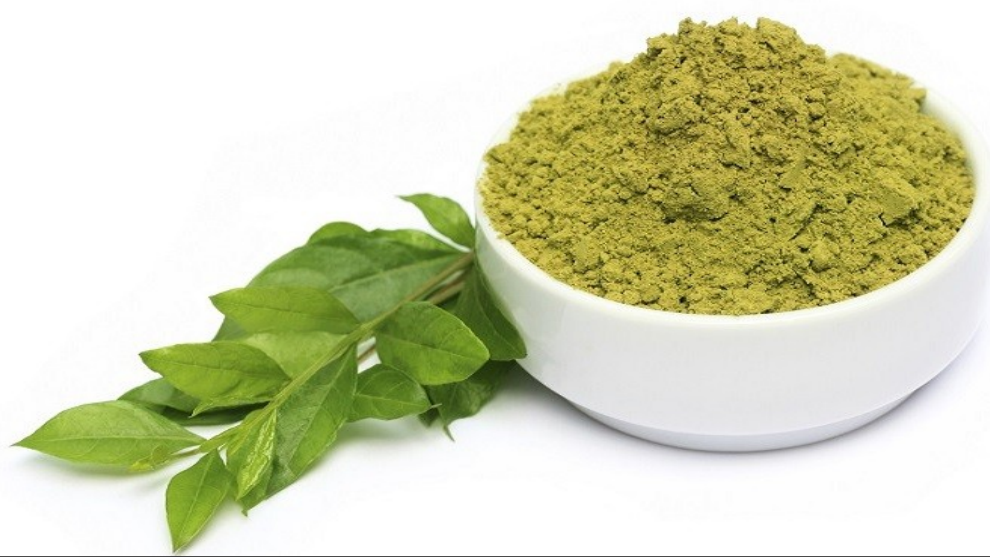

\begin{abstract}
ABS TRACT
Nutraceuticals provides medical and health benefits including the prevention and treatment of a disease. Nutraceuticals are naturally derived bioactive compounds that are found in foods, dietary supplements and herbal products, and have health promoting, disease preventing and medicinal properties. Nutraceuticals are the substances which are not traditionally recognized nutrients but which have positive physiological effects on the human body. Nutraceutical has advantage over the medicine because they avoid side effects. Nutraceuticals are classifying on the basis of their natural source, chemical grouping, nutrients, herbals, dietary supplements and dietary fiber. Herbal nutraceutical is used in maintaining health and act against nutritionally induced acute and chronic diseases, thereby promoting optimal health, longevity, and quality of life. The nutraceutical revolution will lead us into a new era of medicine and health, in which the food industry will become research oriented to the pharmaceutical industry. The present review has been devoted towards understanding of the nutraceuticals from different medicinal plants based on their disease specific indications.
\end{abstract}




\section{Introduction}

The term nutraceuticals was coined from "nutrition" and "pharmaceutical" by Stephen Defelice in 1989 [1] Nutraceuticals are the molecules used singly or in combinations as dietary supplements to complement inborn deficiencies and those that develop with ageing. Nutraceuticals are food or part of a food that provides medical or health benefits including the prevention and treatment of a disease [2]. Some nutraceuticals serve essentially as therapeutics on patients of specific diseases, bulk of them are useful as health giving food supplements. When a functional food aids in the prevention and treatment of diseases and disorders are called nutraceuticals [3]. The functional foods are ordinary foods that have components, ingredients that incorporated into give them a specific medicinal or health benefit moreover nutritional effect [4].Dietary supplements are products intended to supplement the diet that contains one or more of the following dietary ingredients such as vitamins, minerals, herbs or other botanicals, amino acids, dietary substances for uses[ㅍ] It may be taken in the form of pills, capsule, tablet, or liquid forms. It is not represented for use as a conventional food or as the sole item of a meal or diet. These dietary supplements are responsible for ensuring that the dietary supplements are safe before it is marketed. Simply, Nutraceuticals means, Nutritive + Pharmaceutical- A food stuff that provides health benefits. The Food products are taken as part of the usual diet in order to have beneficial effects that go beyond basic nutritional function.

Consumption of junk food has increased manifold, which has led to a number of diseases related to nutritional deficiencies. Nutraceuticals can play an important role in controlling them. No wonder more and more people are turning to nutraceuticals [1, 6-9]. It concluded that diet is rated more highly by consumer then exercise or hereditary factors to achieving a good health. Nutraceuticals is a product isolated or purified from the food, generally sold in medicinal form not associated with food and demonstrated to have a physiological benefit and also provides benefit against chronic disease[10]. A functional food has a component incorporated into it to give it a specific medical or physiological benefit, other than purely nutritional benefit [11]. There is a slight difference between the functional foods and nutraceuticals. When food is being cooked or prepared using with or without knowledge of how or why it is being used, the food is called functional food. Functional food provides the body with the required amount of vitamins, fats, proteins, carbohydrates, etc. needed for its healthy survival. When functional food aids in the prevention and treatment of diseases and disorders other than anaemia, it is called a nutraceutical. Examples of nutraceuticals include fortified dairy products and citrus fruits $[\underline{4}, \underline{12}]$. The dietary supplement[13-15]:

- It's a product (except tobacco) that is intended to supplement the diet that contains one or more of the following dietary ingredients like vitamin, mineral, herb or other botanicals, amino acids or dietary substances for use to supplement the diet by increasing the total daily intake.

- It's intended for ingestion in pills, capsules, tablets or liquid forms.

- It's not represented for use as a conventional food or as the sole item of a meal or diet.

- It's labelled as a "dietary supplement".

Functional foods and nutraceuticals may offer many benefits:

- It's may increase the health value of our diet.

- It may help us live longer.

- It may help us to avoid particular medical conditions.

-It may have a psychological benefit from doing something for oneself. 
-It may be perceived to be more "natural" than traditional medicine and less likely to produce unpleasant side-effects.

- It may present food for populations with special needs (nutrient-dense foods for the elderly).

- It avoid the side effect.

- It may have naturally dietary supplement, so do not have unpleasant side effect.

- It may increase the health value, our diet and improve medical condition of human.

- It may easily be available and economically affordable. Nutritional therapy is a healing system using dietary therapeutics or nutraceuticals as a complementary therapy. This therapy is based on the belief that foods can not only be sources of nutrients and energy but could also provide medicinal benefits.

According to nutraceutical and nutritional therapy theory, it achieves this goal by using efficacy of such nutraceuticals in detoxifying the body, avoiding vitamin and mineral deficiencies, and restoring healthy digestion and dietary habit. Phytonutrients basically is plant nutrients with particular biological activities in supporting human health [16].

The phytochemical work is carried out by following ways such as: substrate for biochemical reactions, cofactors of enzymatic reactions, Inhibitors of enzymatic reactions, absorbents that bind to and eliminate undesirable constituent in the intestine, enhance the absorption and/or stability of essential nutrients, selective growth factor for beneficial bacteria, fermentation substrate for beneficial bacteria, selective inhibitors of deleterious intestinal bacteria, scavengers of reactive or toxic chemicals, ligands that agonize or antagonize cell surface or intracellular receptors [17]. Nutraceuticals are foods or food ingredients that provide medical or health benefits. This emerging class of products blurs the line between food and drugs [18]. They do not easily fall into the legal categories of food or drug and often inhabit a grey area between the two [19].
Thus, if the substance contributes only to the maintenance of healthy tissues and organs it may be considered to be a food ingredient. If, however, it can be shown to have a modifying effect on one or more of the body's physiological processes and considered to be a medicinal substance [무]. A nutraceutical can be defined as a medicine for two reasons: 1) It can used for the prevention, treatment or cure of a condition or disease or

2) It can be administered with a view to restoring, correcting or modifying physiological functions in human beings.

Foods as nutraceuticals: A nutraceutical is the opposite of junk food and according to the WHO, over $80 \%$ of the world's population rely upon such traditional plant-based systems of medicine as phytochemicals, nutritional constituents or as functional food [21]. Functional foods are ordinary foods that have components, ingredients, incorporated in them to give them a specific medicinal or physiological benefit other than a purely nutritional effect [1]. Although the distinction between medicinal plants and Nutraceuticals can sometimes be vague, a primary characteristic of the latter is that Nutraceuticals have a nutritional role in the diet and the benefits to health may arise from long-term use as foods. The preparations based on them have also been called as functional foods. The economic production and availability of Nutraceuticals is a highly desirable objective to improve the health of the people of the country, especially that of the poor people. The nutraceuticals related research for improving its quality and quantity is an important area for ongoing biotechnological investigations. Nutraceuticals are essentially prophylactic or preventive, in contrast to drugs, which are active chemical substances used for preproduction or to treat an illness [22, 23]. They represent a different approach, one based on nutrition for curing ill health or overall wellness of the whole body, rather than drug based curing of diseases [24, 25] 
Nutraceuticals or functional foods can be classified on the basis of their natural sources, pharmacological parameters or according to their chemical constitution. The most usual nutraceuticals are Nutrients, herbals, dietary supplements, functional food and natural chemicals derived from different medicinal plants [두]

\subsection{CLASSIFICATION OF NUTRACEUTICALS}

Regarding the promise of nutraceuticals, they should be considered in two ways:

- Potential nutraceuticals

- Established nutraceuticals

A potential nutraceutical is one that holds a promise of a particular health or medical benefit; such a potential nutraceutical only becomes an established one after there are sufficient clinical data to demonstrate such a benefit. It is disappointing to note that the overwhelming majority of nutraceutical products are in the 'potential' category, waiting to become established [27]. The food products used as nutraceutical are categorized as [료]

Nutraceuticals or functional foods can be classified on the basis of their natural sources, pharmacological conditions, or as per chemical constitution of the products.

1. On the basis of natural source, it can be classified as the products obtained from plants, animals, minerals, or microbial sources.

2. Nutraceuticals as per the chemical groupings.

\subsection{Category of Nutraceuticals}

- Substances with established nutritional functions, such as vitamins, minerals, amino acids, and fatty acidsNutrients.

- Herbs or botanical products as concentrates or extracts-Herbals.

- Reagents derived from other sources (e.g., pyruvate, chondroitin sulfate, steroid hormone precursors) serving specific functions, such as sports nutrition, weight-loss supplements, fortified conventional foods, and meal replacements-Dietary supplements.

Dietary supplements are not intended to treat or cure disease[ $\underline{5}, \underline{29}]$, whereas nutraceuticals more emphasize the expected results of these products, such as prevention or treatment of diseases [30]. Some of the most common ways of classifying nutraceuticals can be based on food sources, mechanism of action, chemical nature, etc. The food sources used as nutraceuticals are all natural and can be categorized as; Dietary Fibber, Probiotics, Prebiotics, Polyunsaturated fatty acids, Antioxidant vitamins, Polyphenols, Spices, Nutraceutical can be broadly classified into the following 2 groups:

i) Potential nutraceuticals.

ii) Established nutraceuticals.

A potential nutraceutical could become an established one only after efficient clinical data of its health and medical benefits are obtained $[\underline{28}, \underline{31}]$.

\subsection{Area covered by nutraceutical products}

All therapeutic areas such as anti-arthritic, pain killers, cold and cough, sleeping disorders, digestion and prevention of certain cancers, osteoporosis, blood pressure, cholesterol, depression and diabetes have been covered by nutraceuticals.

Nutraceuticals revolution: The nutraceuticals revolution began in the early 1980s, sparked off when the actual or potential clinical benefits of calcium, fiber and fish oil were supported by clinical studies published in distinguished medical journals, and when physicians began to educate their colleagues and consumers about these substances via the mass media.

Factors effecting Revolution

- Physician-Increased physician acceptance of the medical benefits of nutritional products increased market demand of nutraceuticals.

- Media-The mass media have emerged as the primary sources of medical claims, mass media has now become 
the powerful and legitimate promotion agency of nutraceutical products.

Nutrients: Substances with established nutritional functions, such as carbohydrate, proteins, vitamins, minerals, amino acids and fatty acids. The commonly known nutrients are antioxidants, vitamins and essential minerals. Antioxidants are retard or prevent deterioration, damage or destruction caused by oxidation. Antioxidant form an integral part of the nutraceutical market [32] The Phyto-nutrients are unique substances occur naturally in plants, hold specific and powerful disease preventing possibilities $[\underline{33}, \underline{34}]$. Both essential and nonessential phytonutrients should be considered as bioactive food components based on the specific physiological function they impart, including characterization of their metabolic and physiological functions and associated targets, and biomarkers. Fruits and vegetables give us many of the nutrients that we need: vitamins, minerals, dietary fiber, water, and healthful phytochemicals [35] .

\subsection{Natural products as nutraceuticals:}

Almost all fruits and vegetables naturally have essential minerals, and that are low in fat and calories with no cholesterol.

Table 1. Chemical classification of nutraceuticals.

\begin{tabular}{lll}
\hline No. & Class Example & Class Example \\
\hline $\mathbf{1}$ & Inorganic mineral supplements & Minerals \\
$\mathbf{2}$ & Vitamin supplements & Vitamins \\
$\mathbf{3}$ & Digestive enzymes & Enzymes \\
$\mathbf{4}$ & Probiotics & Lactobacillus \\
& & acidophilus \\
$\mathbf{5}$ & Prebiotics & Digestive enzymes \\
$\mathbf{6}$ & Dietary fibers & Fibers \\
$\mathbf{7}$ & Cereals and grains & Fibers \\
$\mathbf{8}$ & Health drinks & Fruits juice \\
$\mathbf{9}$ & Antioxidants & Vitamin c \\
$\mathbf{1 0}$ & Phytochemicals & Carotenoids \\
$\mathbf{1 1}$ & Herbs as a functional foods & Soya proteins \\
\hline
\end{tabular}

Table 2: Various vitamins and their health benefits

\begin{tabular}{|c|c|c|c|}
\hline No. & Vitamins & Source & Health benefits \\
\hline 1 & Vitamin $A_{1}$ & Fish liver oil, liver & Antioxidants \\
\hline 2 & Vitamin $A_{2}$ & $\begin{array}{l}\text { Cheese, butter } \\
\text { carrots, spinach, } \\
\text { pumpkins, papaya }\end{array}$ & $\begin{array}{l}\text { maintenance of } \\
\text { healthy skin, vision } \\
\text { and mucous } \\
\text { membrane }\end{array}$ \\
\hline 3 & Vitamin D & $\begin{array}{l}\text { Fish liver oil, } \\
\text { wheat germ oil, egg } \\
\text { yolk, milk, butter }\end{array}$ & $\begin{array}{l}\text { Essential for formation } \\
\text { of bones and teeth, } \\
\text { helps the body absorb } \\
\text { and use calcium }\end{array}$ \\
\hline 4 & Vitamin E & $\begin{array}{l}\text { Wheat germ oil, } \\
\text { cotton seed oil, } \\
\text { peanut oil }\end{array}$ & $\begin{array}{l}\text { Antioxidant, helps } \\
\text { form blood cells, } \\
\text { muscles, lung and } \\
\text { nerve tissue, boosts } \\
\text { the immune system }\end{array}$ \\
\hline 5 & Vitamin $\mathrm{K}$ & $\begin{array}{l}\text { Cabbage, } \\
\text { cauliflower, } \\
\text { tomatoes }\end{array}$ & $\begin{array}{l}\text { Essential for blood } \\
\text { clotting }\end{array}$ \\
\hline 6 & Vitamin $B_{1}$ & Cereals, pulses & Essential in neurologic \\
\hline 7 & Vitamin $B_{2}$ & Nuts, yeast & $\begin{array}{l}\text { Helps in energy } \\
\text { production }\end{array}$ \\
\hline 8 & $\begin{array}{l}\text { Vitamin } B_{3} \\
\text { (pantothe } \\
\text { nic) }\end{array}$ & Liver, meat, yeast & $\begin{array}{l}\text { Helps to convert food } \\
\text { in to energy and } \\
\text { maintain proper brain } \\
\text { function }\end{array}$ \\
\hline 9 & Folic acid & Green vegetables & $\begin{array}{l}\text { Essential in pregnancy, } \\
\text { helps in RBC } \\
\text { formation }\end{array}$ \\
\hline 10 & $\begin{array}{l}\text { Nicotinic } \\
\text { acid }\left(B_{5}\right)\end{array}$ & Yeast, egg, milk & $\begin{array}{l}\text { Required for various } \\
\text { nervous system } \\
\text { function }\end{array}$ \\
\hline 11 & $\begin{array}{l}\text { Pyridoxine } \\
\text { (B6) }\end{array}$ & $\begin{array}{l}\text { Banana, tomato } \\
\text { juice }\end{array}$ & $\begin{array}{l}\text { Helps to produce } \\
\text { essential proteins and } \\
\text { convert protein in to } \\
\text { energy }\end{array}$ \\
\hline 12 & $\begin{array}{l}\text { Biotin } \\
\text { (Vitamin } \\
\text { H) }\end{array}$ & Swiss chard & $\begin{array}{l}\text { Required for various } \\
\text { metabolic functions }\end{array}$ \\
\hline
\end{tabular}

Herbals: The knowledge of herbals has accumulated over thousands of years and today we have many effective means of ensuring health care. Numerous nutraceuticals are present in medicinal herbs as key components [36-38]. A great attention has, now a day's, been given to discover the link between dietary nutrients and disease prevention. Large number of herbs, which had been in use since ancient time, have been shown to play a crucial role in the prevention of disease. In addition to the macro and micro nutrients such as proteins, fats, carbohydrates, vitamins or minerals necessary for normal metabolism, a plant based diet contains numerous non nutritive phytoconstituents which may also play an important role in health enhancement [39-42]. 
Table 3. List of important macro and micro nutrient from fruit and vegetable source.

\begin{tabular}{|c|c|c|c|}
\hline No. & Nutrient & Fruit Sources & Vegetable Sources \\
\hline 1 & Calcium & $\begin{array}{l}\text { Blackberries, } \\
\text { Blackcurrants, Dates } \\
\text { Grapefruit, } \\
\text { Mulberries, Orange, } \\
\text { Pomegranate }\end{array}$ & $\begin{array}{l}\text { Amaranth leaves, } \\
\text { Celery } \\
\text { Chinese Broccoli, } \\
\text { French Beans, Okra, } \\
\text { Spirulina, Turnip }\end{array}$ \\
\hline 2 & Copper & $\begin{array}{l}\text { Avocado, } \\
\text { Blackberries, Dates, } \\
\text { Guava, Lychee, } \\
\text { Mango, Pomegranate }\end{array}$ & $\begin{array}{l}\text { Amaranth leaves, } \\
\text { French, beans, Peas, } \\
\text { Potatoes,Pumpkin, } \\
\text { Spirulina, Sweet } \\
\text { Potato }\end{array}$ \\
\hline 3 & Iodine & $\begin{array}{l}\text { Iodine Fruits grown } \\
\text { in iodine-rich soils } \\
\text { contain iodine. }\end{array}$ & $\begin{array}{l}\text { Vegetables grown in } \\
\text { iodine-rich soils } \\
\text { contain iodine. }\end{array}$ \\
\hline 4 & Iron & $\begin{array}{l}\text { Blackberries, } \\
\text { Cherries, Dates, Figs, } \\
\text { Grapes, Kiwi, Lychee, } \\
\text { Mulberries, } \\
\text { Pomegranate, } \\
\text { Strawberry, } \\
\text { watermelon }\end{array}$ & $\begin{array}{l}\text { Amaranth leaves, } \\
\text { French Beans, Peas, } \\
\text { Potatoes, Spinach, } \\
\text { Turnip }\end{array}$ \\
\hline 5 & $\begin{array}{l}\text { Magnesi } \\
\text { um }\end{array}$ & $\begin{array}{l}\text { Banana, } \\
\text { Blackberries, } \\
\text { Blackcurrants, Dates, } \\
\text { Guava, Mulberries, } \\
\text { Raspberries, } \\
\text { pomegranate, } \\
\text { Watermelon, }\end{array}$ & $\begin{array}{l}\text { Amaranth leaves, } \\
\text { Butternut squash, } \\
\text { French Beans, Okra, } \\
\text { Peas }\end{array}$ \\
\hline 6 & $\begin{array}{l}\text { Mangan } \\
\text { ese }\end{array}$ & $\begin{array}{l}\text { Banana, } \\
\text { Blackberries,Blackcu } \\
\text { rrants, Blueberries, } \\
\text { Dates, Grapefruit, } \\
\text { Guava, Pomegranate, } \\
\text { Raspberries, } \\
\text { Strawberry }\end{array}$ & $\begin{array}{l}\text { French Beans, Lima } \\
\text { Beans, Okra, Peas } \\
\text { Potatoes, Sweet } \\
\text { Potato }\end{array}$ \\
\hline 7 & $\begin{array}{l}\text { Phosph } \\
\text { orus }\end{array}$ & $\begin{array}{l}\text { Avocado, Dates, } \\
\text { Guava, Lychee, } \\
\text { Mulberries, } \\
\text { Pomegranate }\end{array}$ & $\begin{array}{l}\text { Amaranth leaves, } \\
\text { Brussels Sprouts, } \\
\text { Corn, French Beans, } \\
\text { Parsnip, Potatoes, } \\
\text { Pumpkin }\end{array}$ \\
\hline 8 & $\begin{array}{l}\text { Potassiu } \\
\mathrm{m}\end{array}$ & $\begin{array}{l}\text { Bananas, Cherries, } \\
\text { Dates, Guava, } \\
\text { Grapefruit, } \\
\text { Pomegranate, } \\
\text { Watermelon }\end{array}$ & $\begin{array}{l}\text { Amaranth leaves, } \\
\text { Bamboo Shoots, } \\
\text { French Beans, } \\
\text { Parsnips, Potatoes, } \\
\text { Pumpkin, Sweet } \\
\text { Potatoes }\end{array}$ \\
\hline 9 & $\begin{array}{l}\text { Selaniu } \\
\mathrm{m}\end{array}$ & $\begin{array}{l}\text { Bananas, Guava, } \\
\text { Lychee, Mango, } \\
\text { Pomegranate, } \\
\text { Watermelon }\end{array}$ & $\begin{array}{l}\text { Asparagus, French } \\
\text { Beans, Lima Beans, } \\
\text { Mushrooms, Peas }\end{array}$ \\
\hline 10 & Sodium & $\begin{array}{l}\text { in almost all fresh, } \\
\text { wholefruits }\end{array}$ & $\begin{array}{l}\text { Sodium occurs } \\
\text { naturally inalmost all } \\
\text { fresh, whole } \\
\text { vegetables }\end{array}$ \\
\hline 11 & Zinc & $\begin{array}{l}\text { Blackberries, Dates, } \\
\text { Pomegranate, } \\
\text { Raspberries }\end{array}$ & $\begin{array}{l}\text { Asparagus, Bamboo } \\
\text { Shoots, Corn, French } \\
\text { Beans, Okra, Peas, } \\
\text { Potatoes, Pumpkin }\end{array}$ \\
\hline
\end{tabular}

Neutraceutical herbal plants and the information on specified organs of these plants that serve as source of material that can be used directly or in the form of processed products. The table also mentions the conditions for which the plant materials have proved useful. There is need for domestication and cultivar development for cultivated production of these plants. The post-harvest processing technologies that will allow material to remain active and hygienic also needs to be worked out for a large majority of these plants.

Functional food: They are consumed as apart of normal diet and are intended to supplement the normal diet. Functional foods are similar to conventional food or beverage and are consumed as part of a normal diet having physiological benefits. They can also promote growth and developmental processes. They may be used as conventional or fortified foods with bioactive components to reduce disease risk.

\subsection{Dietary supplements:}

They are concentrated sources of nutrients or other substances with a nutritional or physiological effect, alone or in combination. Dietary supplements contain all products that can be purchased by the consumer without prescription. Many potential benefits have been attributed to antioxidant use in the form of dietary intake or supplementation. Antioxidants, in general, may be useful in the prevention of cancer and cerebrovascular disease. Dietary supplements are not classified as drugs. The main difference is that they do not have approved therapeutic claims unlike in the case of drugs. Moreover, dietary supplements could either contain vitamins, minerals, herbals, or amino acids, all aimed to add to or supplement the diet of an individual. They are not intended to betaken alone as a substitute to any food or medicine [43].

The Nutraceuticals market comprises two principal segments: Functional Foods and Dietary Supplements. 
Table 4.List of some common medicinal plants used as traditional herbal Nutraceuticals

\begin{tabular}{|c|c|c|c|c|}
\hline No. & Plant species & Common name & Diseases for which Used Form of use & Form of use \\
\hline 1 & Agave americana & Rambans & Antiseptic, diurectic & Leaves sap \\
\hline 3 & Allium sativum & Garlic & $\begin{array}{l}\text { Chemopreventation, cancer, diabetes, } \\
\text { arteriosclerosis, lowering cholesterol, } \\
\text { respiratory infections }\end{array}$ & $\begin{array}{l}\text { Fresh or dried cloves,capsules, } \\
\text { odorlesstablets, tinctures, aged } \\
\text { garlic extracts }\end{array}$ \\
\hline 3 & Aloe vera & Ghritkumari & $\begin{array}{l}\text { First-degree burns, cuts and abrasions, } \\
\text { wound healing, anthelmint, antiulcer }\end{array}$ & $\begin{array}{l}\text { Sunscreen, skin creams, lotions, } \\
\text { oralintake }\end{array}$ \\
\hline 4 & Avena sativa & Oat straw & $\begin{array}{l}\text { Diuresis, cholesterol control, reducing } \\
\text { inflammation, itching }\end{array}$ & Dried herb; capsules,tablets, tinctures \\
\hline 5 & Amaranthus spp. & Chaulai & Cardiovascular disease & oil from seeds \\
\hline 6 & $\begin{array}{l}\text { Andrographis } \\
\text { paniculata }\end{array}$ & Kalmegha & $\begin{array}{l}\text { Bacillary dysentery, respiratory tract } \\
\text { Infection }\end{array}$ & Shoot powder \\
\hline 7 & Artemisia annua & Artemisia & Fever, upperrespiratory tractinfections & Shoot decoction \\
\hline 8 & Asparagus spp. & Shatavari & Tonic, astringent & Roots \\
\hline 9 & Borago officinalis & Bugloss, & $\begin{array}{l}\text { Skin care, anti-inflammatory, } \\
\text { bloodpurifier. }\end{array}$ & Herb, Leaves and Flowers \\
\hline 10 & Boswellia serrata & Salai guggal & Asthma, anti-arthritic & Gum-resin \\
\hline 11 & Bauhinia purpuria & Rakta kanchan & Catarrh, boil, glandular swelling & Roots and leaves \\
\hline 12 & Berberis asiatica & Barberry & $\begin{array}{l}\text { Roots are used intreating ulcers, urethral } \\
\text { discharges, ophthalmia, jaundice, fevers } \\
\text { etc fruit iscooling and laxative }\end{array}$ & Roots and berries \\
\hline 13 & Calendula spp & Pot marigold & $\begin{array}{l}\text { Anti-inflammatory, may inhibit HIV, } \\
\text { antibacterial, antitumor. Skin and cancer } \\
\text { treatments. }\end{array}$ & Floweral decoction for wound healing \\
\hline 14 & Capsicum annum & Red pepper & $\begin{array}{l}\text { Anti-arthritic, antioxidant action, } \\
\text { stimulant, nutrition, rubefacient, nutrition }\end{array}$ & Fresh and dried fruit,powder \\
\hline 15 & Cassia senna & Senna & Constipation & Dried leaf, /pods \\
\hline 16 & Centella asiatica & Gotu kola & $\begin{array}{l}\text { Improving memory, sedative, } \\
\text { stressreduction, imunostimulant, venous } \\
\text { insufficiency, wound } \\
\text { healing pregnancy related stretch } \\
\text { marks,venous tonic }\end{array}$ & $\begin{array}{l}\text { Herb, powdered,capsules, tablets, } \\
\text { tinctures, teas }\end{array}$ \\
\hline 17 & Curcuma longa & Turmeric & $\begin{array}{l}\text { Reducinginflammation, indigestion, } \\
\text { antioxidant, liverproblem }\end{array}$ & Dried root, whole, Powdered \\
\hline 18 & $\begin{array}{l}\text { Commiphora } \\
\text { Wightii }\end{array}$ & Guggal & $\begin{array}{l}\text { Cardioprotective, antiinflammatory, } \\
\text { rheumatic deseases }\end{array}$ & Gum -resin \\
\hline 19 & $\begin{array}{l}\text { Cymbopogon } \\
\text { Citrates }\end{array}$ & Lemon grass & Stomachache, expelling gas & Dried leaf, cut andsifted, tea \\
\hline 20 & $\begin{array}{l}\text { Echinacea } \\
\text { angustifolia, } \\
\text { purpurea, pallid }\end{array}$ & Echinacea & $\begin{array}{l}\text { Cold, flu, minorinfections, } \\
\text { immunostimulant }\end{array}$ & $\begin{array}{l}\text { Dried whole herb orroot, capsules, } \\
\text { expressed juice of fresh flowering plants, } \\
\text { flex-tabs, tablets,tinctures }\end{array}$ \\
\hline 21 & Ephedra sinica & Ephedra & $\begin{array}{l}\text { Mild anti-asthmatic, nasal congestion, } \\
\text { broncho-dilator, fluid retention, obesity }\end{array}$ & Dried-stems; capsules,tablets, tinctures \\
\hline 22 & $\begin{array}{l}\text { Echinacea } \\
\text { angustifolia }\end{array}$ & Cone flower & $\begin{array}{l}\text { Antibiotic, antiviral and anti allergic used } \\
\text { inreducing the commoncold. }\end{array}$ & Whole plant \\
\hline 23 & $\begin{array}{l}\text { Foeniculum } \\
\text { vulgare }\end{array}$ & Fennel & $\begin{array}{l}\text { Stomach bloating, stimulant, } \\
\text { digestivespasms, catarrh aphrodisiac, } \\
\text { galactogogue }\end{array}$ & Whole seed, capsules, Tinctures \\
\hline 24 & Ginkgo biloba & Ginkgo & $\begin{array}{l}\text { Age-related memory loss, fatigue, } \\
\text { tinnitus,anti-arthritic, improving } \\
\text { microcirculation }\end{array}$ & Dried leaf, tea \\
\hline 25 & Glycyrrhiza glabra & Licorice & $\begin{array}{l}\text { Anti-inflammatory, congestion, coughs, } \\
\text { stomach or duodenalulcers }\end{array}$ & $\begin{array}{l}\text { Root powder, capsules, extracts, tablets, } \\
\text { tinctures }\end{array}$ \\
\hline 26 & Garcinia cambogia & Garcinia & Weight loss & Extracts of fruit \\
\hline 27 & $\begin{array}{l}\text { Hypericum } \\
\text { perforatum }\end{array}$ & $\begin{array}{l}\text { St.-John's- } \\
\text { Wort }\end{array}$ & $\begin{array}{l}\text { Mild to moderateepilepsy, depression, } \\
\text { cuts and abrasions }\end{array}$ & $\begin{array}{l}\text { Dried herb, floweringtops for tea, in oil } \\
\text { forexternal use, capsulestablets, } \\
\text { tinctures }\end{array}$ \\
\hline 28 & Hibiscus subdariffa & Motherwort & CNS depressant & Calyx powder or Decoction \\
\hline 29 & $\begin{array}{l}\text { Linum } \\
\text { usitatissimum }\end{array}$ & Flaxseed & $\begin{array}{l}\text { Constipation, irritablebowel syndrome, } \\
\text { source of omega-3-essential fatty acids, }\end{array}$ & Seed powder, expressed oil of seed \\
\hline
\end{tabular}


cholesterol ontrol, chemoprevention,

anti-arthritic

$\begin{array}{lll}30 & \begin{array}{l}\text { Matricaria } \\ \text { chamomilla }\end{array} & \text { Chamomile } \\ \mathbf{3 1} & \begin{array}{l}\text { Medicago sativa } \\ \text { 32 }\end{array} & \text { Alfalfa } \\ \text { Moringa oleifera } & \text { Moringa }\end{array}$

Panax
quinquefolius and
ginseng

ginseng

34

Plantago ovata

35

Puereria tuberosa

36

Rosmarinus

officinalis

$37 \quad$ Phyllanthus

Emblica

38

Serenoa repens

39

Silybum marianum

40

Swertia chirata

41 Trigonella foenumgraecum

42

Urtica dioica

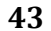

Terminalia chebula

44 Valeriana

officinalis

Withania

somnifera
Ginseng

Psyllium

Bilikand

Sedative, indigestion, insomnia, nausea,

inflammation, woundhealing

Appetite stimulation, anti-arthritic, nutrition

Uses include as anantimicrobial, antiviral, hepatoprotective, anti-cancerous, antiseptic and intreating rheumatism, skin diseases, asthama andvenomous bites

Convalescence, fatigue, diabetes, cholesterol control, Improving concentration and wellbeing, aphrodisiac Constipation, lowering cholesterol, type 2 Diabetes

Eases bowel movement, useful inrelieving constipation, used in skin diseases

Digestion, rheumatism, stimulating

appetite, stimulating circulation

Stress, diuretic, liver function, anti-

ageing,diabetes

Amla

Saw palmetto

Benign prostatichyperplasia, inflammation, impotence

Milk thistle Liver disorders, lactation problems, antioxidant

Chirata Migraine headaches

Fenugreek

Stinging nettle

Gastritis, excesscholesterol, diabetes, nutrition, skininflammation

Benign prostatichyperplasia (BPH),

diuresis, anemia,

Osteoarthritis

Antioxidant, Anxiety, insomnia

, Hypertension

Valerian

Ashwagandha

Stress, insomnia, cataract prevention

Indigestion, motion sickness, nausea, antioxidant,cholesterolcontrol
Dried flowers, capsules, cream, salve, tea, tincture, bath products

Dried leaf, capsules, extracts, tablets, tinctures, teas

tree's bark, roots, fruit, flowers, leaves, seeds, and gum

Dried root, steamed root, capsules, extracts, tablets, tinctures, teas

Dried seed, husk, capsules

Tubers

Leaf powdered, tinctures, extracts

Fruit pulp fresh or dry

Dried fruit whole, ground, capsules, tablets, tinctures

Whole or powderedseed, capsules,tablets, tinctures Fresh or dried wholeplant Seed, whole or powdered; capsules,tinctures

Dried leaf, dried root;capsules, tablets,tinctures

Fruit pulp

Root, powder, tea, capsules, tablets, tinctures, extracts

Root powder, standardized

extracts,tinctures

Fresh or dried root, capsule, tablets, Tinctures

\section{Phytochemicals: Phytochemicals are naturally} occurring biochemicals that give plants their colour, flavour, smell, and texture, which may help prevent diseases [44]. They are biologically active natural products such as glucos inolates in cruciferous vegetables, limonoids in citrus fruits, lignans in flaxseed, lycopene in tomatoes, and catechins intea. They all have specific actions and can be used variously for e.g. as antioxidants and have a positive effect on health $[\underline{23}, \underline{30}$, 45, 46].Numerous laboratories began studying phytochemicals to "mine" plants for bioactive substances that might be used as medicines or nutraceuticals or for other chemical applications. Many compounds are showing great promise as disease fighters in the body, boosting production or activities of enzymes, which then act by blocking carcinogens, suppressing malignant cells, or interfering with the processes that can cause heart disease and stroke[4 $\underline{4-}$ 49]. Systematic classification on the basis of therapeutically important compounds of the Nutraceuticals are responsible for the specific health benefit.

Recently, much attention has been given to phytochemicals that possess cancer preventive properties [46, 47]. Beside schemopreventive components in vegetables and fruits, some phytochemicals derived from herbs and spices also have 
potential anti-carcinogenic and anti-mutagenic activities, among other beneficial health effect.

Table 5. List of some common chemical compounds isolated from plants used as Nutraceuticals[ $\underline{50-74}]$.

\begin{tabular}{ll}
\hline S No. & Chemical compounds/source \\
\hline $\mathbf{1}$ & Allicin from Allium sativum
\end{tabular}

Properties

It is a powerful antifungal antibacterial. It has been shown to be an antioxidant and has been used to treat arteriosclerosis and serum cholesterol [무] .

2

Betaine (Trimethyl Glycine) from green leafy vegetables and germinated grains

Bromelain from Ananas sp.

4

Camphor from Cinnamomum

Camphora

5

Capsaicin or trans-8-methyl-

$\mathrm{N}$-vanillyl-5 nonenamide

from Capsicum annum

6

Carnitine or L-Carnitine from

Asparagus

7

Ellagic Acid from

strawberries and raspberries

8

Ricinoleic acid from Castor

Oil or Ricinus communis

9

Chocolate ( a mixture of cocoa obtained from

Theobroma cacao and vanilla from orchid)

Curcumin from Curcuma longa

11 Plant Glucosamine

12 Glutathione (GSH),

13

Hesperitin

14

Hydroxy Citric Acid
Reduces toxic buildup of homocysteine [ $\underline{51}$.

Used as an inhalant to treat cold and flu [르].

Used as an inhalant to treat cold and flu [푹.

Used for pain relief topically and as a digestive aid when taken internally. It is also seen as a possible antioxidant for the body. It can pose a risk of allergic reactions and the severe damage to the eyes or skin if used in higher doses[54].

Responsible for the transportation of long-chain

fatty acids groups into the mitochondria [ㄷ5].

this phytochemical fights cancer in humans [ㅌ6].

Contains ricinoleic acid the active ingredient. Castor oil is used both externally (multiple skin problems) and internally for constipation, upper respiratory problems, and liver and kidney issues [57].

Have positive effects on the heart and blood pressure due to the flavonoids in chocolate. Chocolate also contains a neurotransmitter, serotonin, that acts as an antidepressant, and other substances, such as theobromine and phenylethylamine. These have a stimulating effect [58].

The colorant in turmeric a fraction of which has been shown by studies done at the University of California in Los Angeles to clear brain plaque caused by Alzheimer's disease [59].

Chondroitin and glucosamine are part of normal cartilage and acts as a cushion between the joints [됴].

A tripeptide, which provides antioxidant properties thereby protecting the cells against damage by free radicals[ $[\underline{60}]$.

Hesperitin is a GRAS ingredient that shows interest as a potential anti-inflammtory [1ㅜ].

Hydroxy Citric Acid found in Garcinia[ $\underline{62}]$. 


Isoquercitin from mangoes and from Rheum
nobile

(Enzyme Modified)

Licorice or Glycirrhizic acid

Lignan from rye, soybean and brocaoli

Lutein and Lutein Esters from marigold

19
Nattokinase

Olive Oil from Olea europaea

Omega 3 Fatty Acids from Linum
usitatissimum
usitatissimum

Phloretin isolated from apple leaves

Phytosterol obtained from

germinated corn

Proanthocyanins from Grapes

Resveratrol especially high

in grape skin

Tall oil: Derived phytosterols

Zeaxanthin
Increases blood flow for varicose veins, and possible use for arterial flow as well. Recent studies have shown possibilities in increased brain functions and it might be useful in the treatment of progressive Alzheimer's disease [주].

Licorice has been used as early as Roman and Greek times as a decongestant, not inflammatory, to treat stomach ulcers [뎌].

Lignans are one of the two major classes of phytoestrogens. Phytoestrogens are antioxidants and have been viewed as reducing ill effects in the body as cellular destruction, aging, etc [65].

Extracted from marigold seeds, and also found in spinach, rosemary and kale, it is a carotenoid which shows healthful eye benefits [6ㅜ․

Natto is fermented soybeans. Nattokinase is the enzyme produced by Bacillus natto used in the fermentation [67].

Olive oil is high in monounsaturated fat and is a healthy oil in maintaining good cholesterol levels [타] .

Among other positive effects (see rest of chart), omega 3 fatty acids have been associated with positive eye health [의].

Obtained from the decomposition of phloridzin and used in the treatment of malaria as a quinine replacer. Studies have shown it inhibits protein kinase $\mathrm{C}$ and effects the sodium/potassium transfer across membranes [70].

Chemicals found naturally in foods that have the ability to lower cholesterol absorption in the digestive tract thereby lowering overall cholesterol levels in the bloodstream [71].

Help with urinary tract infections by inhibiting adhesion of microorganisms like e. coli to the urinary tract wall [ㄹ].

anti-inflammatory, inhibits COX-1 enzyme, blocks adhesion of blood cells to vessel walls shown to reduce skin and breast cancer [72].

Has been seen to reduce arteriosclerosis, and plasma cholesterol in rodents $[\underline{74}]$.

A carotenoid used as an antioxidant. Zeaxanthin is the coloring agent in marigolds and is extracted from them. It is used for eye health and some claim will retard the effect of 'aging eyesight' or Age-Related Macular Degeneration (AMD) [49].
A broad range of phyto-pharmaceuticals with a claimed hormonal activity, called "phyto-estrogens", is recommended for prevention of prostate/breast cancer. Flavonoids have anti-cancerous properties by acting as antioxidants. They are found in citrus fruits, soy foods which are unique dietary source of isoflavones, green tea rich in epigallocate chingallate and curcuma long a rich in curcumin $[\underline{35}, \underline{44}, \underline{75}]$. The main soy bean 
isoflavones, genistein, daidzein, biochanininhibits prostate cancer cell growth. Carotenoids and lycopenes are also important chemicals for human health. Because of the unsaturated nature of lycopene it is considered to be a potent antioxidant and are active oxygen species (ROS) quencher. The fruits and vegetables containing lycopene exert cancer protective effect via a decrease in oxidative and other damage to DNA in humans. Among the carotenes, beta carotene is the most active as antioxidants. The $\beta$-Carotene is the more common form and can be found in yellow, orange, and green leafy fruits and vegetables [ㄷ]. These can be carrots, spinach, lettuce, tomatoes, sweet potatoes, broccoli, cantaloupe, oranges, and winter squash. Another phytochemical Tannins also called proanthocyanidins, detoxify carcinogens and scavenge harmful free radicals. Ellagic acid is a proven anti-carcinogen is used in alternative medicine and to prevent cancer [ㄷ6]. It is present in strawberries, cranberries, walnuts, pecans, pomegranates and the best source is red raspberry seeds.

Prebiotics: Prebiotics are the substances, which reach to colon in intact form i.e. without getting depleted by the gastric $\mathrm{pH}$ and digestive acids. These prebiotics also selectively promote the growth of colonel probiotic bacteria; hence they act as fertilizers for these bacteria. These are collective term for non-digestive but a fermentable dietary carbohydrate that may selectively stimulates growth of certain bacterial groups resident in the colon, such as Bifido bacteria, Lactobacilli considered to be beneficial for the human host[77]. The prebiotic inulin, which is solubledietary fibbers and resistant to digestive enzyme therefore reaches to large intestine or colon essentially intact, where it is fermented by resistant bacteria, Lactobacilli [78]

Probiotics: It is a substance that contains microorganisms or bacteria that are beneficial to the host organism it can be plant or animal. It is known as "Friendly bacteria". Digestive microbes come from uncooked fruits, vegetables, and fermented products that we eat. There are about 400different bacteria living in the human GI tract, among them lactobacillus acidophilus is one of the major component of the probiotic fighter. It enhances the immune system. Lactobacillus acidophilus can reduce the incidence of vaginal infections including thrush and bacterial vaginosis. Bifid bacteria and Streptococcus thermophilus both found in yoghurt can prevent young children suffering from diarrhoea also in treating travelers diarrhoea and rotavirus infection. There are plant based probiotics also available in the market such as SoyBased Probiotics has extended its line of probiotic formulas with the introduction of two new Liquid SoyBased Acidophilus supplements. Probiotics only have a transient effect and regular daily intake is needed to bring about health benefits. There are large numbers of benefits of using probiotics as nutraceuticals. Some of these benefits include: enhancing bowel function, prevention of colon cancer, lowering cholesterol, lowering of blood pressure, improving immune function, reducing infections, reducing inflammation, improving mineral absorption, preventing growth of harmful bacteria, fighting off diseases like candida and eczema, and many more. As these "friendly bacteria" are beneficial for humans similarly there are several of soil bacteria which act as probiotics for plants. They are helpful in promoting the growth, health and yield of crops.

\subsection{Nutraceuticals and their chemical nature:}

Nutraceuticals is a very broad term which includes a variety of substances/compounds ranging from essential metals, large polymers up to bacteria. Chemical nature of nutraceutical depends upon their structure and function. The chemical characteristics can be used for grouping nutraceuticals based upon their chemical nature. This approach allows nutraceuticals to 
be categorized under different molecular/elemental groups and subgroups. For example

1.Amino acid-based substances: amino acids, ally-S compounds, indole, folate and choline

2. Carbohydrates and derivatives: ascorbic acid, oligosaccharides, no starch-polysaccharides

3. Fatty acids and structural lipids: lecithin, fatty acids, oil

4. Isoprenoid derivatives: carotenoids, saponins, tocopherols, simpleterpenes

5. Phenolic substances: coumarins, tannins, lignin, anthocyanins, isoflavones, flavones, flavonols

6. Microbes: probiotics, prebiotics and

7. Minerals: calcium, selenium, potassium, copper, zinc etc.

\subsection{Neutraceutical food technology:}

Nutraceutical food technology or industry places special emphasis on quality control and in this proper inspections are conducted throughout the manufacturing process, including raw material verification, homogeneity testing, weight deviation measurements and package quality sampling. Botanicals can be fractionated to produce a natural colour fraction, an aroma fraction, an anti-oxidant fraction and/or a flavour fraction. This is important in producing nutraceuticals because unwanted strong flavours in certain botanicals such as garlic and rosemary can be separated from the nutraceutical components. Supercritical fluid technology will allow nutraceutical companies to develop products of standardized concentration of active ingredients, and will simultaneously produce nutraceutical products of much higher concentration (higher yields and purity) and quality, than possible by conventional chemical engineering unit operations, such as liquid/liquid extraction, distillation, mechanical micronization, liquid and/or gas phase reactions, etc. Special food preparations are required to meet the needs of children, lactating mothers and elderly people such as nutritious biscuits/laddoos for children, lactating mother. This kind of preparation should be based on the following and suitable additional materials: wheat, gram and soybean flours, Sesame, Amaranth seeds, spinach leaves, jaggary etc. The molecular diagnostics may play a key role in food safety related to genetically modified foods, food borne pathogens and novel nutraceuticals [79]. The DNA microarray technology offers a new dimension of strength in molecular diagnostics by permitting the simultaneous analysis of large sets of genes in the food constituents [미-82].

\subsection{Role of biotechnology in nutraceuticals development:}

Biotechnology has a key role to play in this new area of the food industry focused on the major energyproviding foods. Recently, there has been increased interest in biologically active non-nutritive ingredients from natural products. Major breakthroughs and enormous progress has been made during the past decade in all aspects of biotechnological nutraceutical development. The high priority given by researchers in the production of probiotics and extraction of bioactive components by enzyme or fermentation technology as well as genetic engineering technology [36, 52] .

Changing values in society, for instance with respect to recombinant DNA, and the growing need to explore all the alternative food sources has made the use of this technique in the production of enzymes and of recombinant microorganisms attractive to the food industry Some of the benefits include increased enzyme or metabolite production from recombinant microorganisms, improvement of thermo stability of these metabolites and enzymes and their ability to tolerate large $\mathrm{pH}$ ranges. Genetic engineering has made it possible to isolate particular genes coding for enzymes or other metabolites of our interest, from organisms of unknown genetics. 
Table 6.Common herbals as nutraceuticals

\begin{tabular}{|c|c|c|c|c|}
\hline S No & $\begin{array}{l}\text { Common } \\
\text { name }\end{array}$ & Biological name & Constituent & Health benefits \\
\hline 1 & Garlic & $\begin{array}{l}\text { Dried bulbs of Allium sativum } \\
\text { (Liliaceae). }\end{array}$ & Alliin and allicin & $\begin{array}{l}\text { Anti-inflammatory, antibacterial, } \\
\text { antigout, nervine tonic }\end{array}$ \\
\hline 2 & $\begin{array}{l}\text { Maiden hair } \\
\text { tree }\end{array}$ & $\begin{array}{l}\text { Leaves of Ginkgo biloba } \\
\text { (Ginkgoaceae). }\end{array}$ & $\begin{array}{l}\text { Ginkgolide and } \\
\text { bilobalide }\end{array}$ & $\begin{array}{l}\text { PAF antagonist, memory enhancer, } \\
\text { antioxidant }\end{array}$ \\
\hline 3 & Ginger & $\begin{array}{l}\text { Rhizomes of Zingiber } \\
\text { officinale (Zingiberaceae.) }\end{array}$ & $\begin{array}{l}\text { Zingiberene and } \\
\text { gingerols }\end{array}$ & $\begin{array}{l}\text { Stimulant, chronic bronchitis, } \\
\text { hyperglycemia and throat ache }\end{array}$ \\
\hline 4 & Echinacea & $\begin{array}{l}\text { Dried herb of Echinacea } \\
\text { purpurea (Asteraceae) }\end{array}$ & $\begin{array}{l}\text { Alkylamide and } \\
\text { echinacoside }\end{array}$ & $\begin{array}{l}\text { Anti-inflammatory, } \\
\text { immunomodulator, Antiviral }\end{array}$ \\
\hline 5 & Ginseng & $\begin{array}{l}\text { Dried root of Panax ginseng } \\
\text { (Araliaceae) }\end{array}$ & $\begin{array}{l}\text { Ginsenosides and } \\
\text { Panaxosides }\end{array}$ & $\begin{array}{l}\text { Stimulating immune and nervous } \\
\text { system and adaptogenic properties }\end{array}$ \\
\hline 6 & Liquorice & $\begin{array}{l}\text { Dried root of Glycyrrhiza } \\
\text { glabra (leguminosae) }\end{array}$ & $\begin{array}{l}\text { Glycyrrhizin and } \\
\text { liquirtin }\end{array}$ & $\begin{array}{l}\text { Anti-inflammatory and Anti- } \\
\text { Allergic, Expectorant }\end{array}$ \\
\hline 7 & $\begin{array}{l}\text { St. John's } \\
\text { wort }\end{array}$ & $\begin{array}{l}\text { Dried aerial part of } \\
\text { Hypericum perforatum } \\
\text { (Hypericaceae) }\end{array}$ & $\begin{array}{l}\text { Hypericin and } \\
\text { hyperforin }\end{array}$ & $\begin{array}{l}\text { Antidepressant, against HIV and } \\
\text { hepatitis-c virus }\end{array}$ \\
\hline 8 & Turmeric & $\begin{array}{l}\text { Rhizome of Curcuma Longa } \\
\text { (Zingiberacae) }\end{array}$ & Curcumin & $\begin{array}{l}\text { Anti-inflammatory, antiarthritic, } \\
\text { anticancer and antiseptic }\end{array}$ \\
\hline 9 & Onion & $\begin{array}{l}\text { Dried bulb of Allium cepa } \\
\text { Linn. (Liliaceae) }\end{array}$ & Allicin and alliin & $\begin{array}{l}\text { Hypoglycemic activity, Antibiotic } \\
\text { and antiatherosclerosis }\end{array}$ \\
\hline 10 & Valeriana & $\begin{array}{l}\text { Dried root of Valeriana } \\
\text { officinalis Linn. } \\
\text { (Valerianaceae) }\end{array}$ & $\begin{array}{l}\text { Valerenic acid and } \\
\text { valerate }\end{array}$ & $\begin{array}{l}\text { Tranquillizer, migraine and } \\
\text { menstrual pain, intestinal cramps, } \\
\text { bronchial spasm. }\end{array}$ \\
\hline 11 & Aloes & $\begin{array}{l}\text { Dried juice of leaves Aloe } \\
\text { barbadensis Mill. (Liliaceae) }\end{array}$ & Aloins and aloesin & $\begin{array}{l}\text { Dilates capillaries, anti- } \\
\text { inflammatory, emollient, wound } \\
\text { healing properties }\end{array}$ \\
\hline 12 & Goldenseal & $\begin{array}{l}\text { Dried root of Hydrastis } \\
\text { Canadensis. (Ranunculaceae) }\end{array}$ & $\begin{array}{l}\text { Hydrastine and } \\
\text { berberine }\end{array}$ & $\begin{array}{l}\text { Antimicrobial, astringent, } \\
\text { antihemorrhagic, treatment of } \\
\text { mucosal inflammation }\end{array}$ \\
\hline 13 & Senna & $\begin{array}{l}\text { Dried leaves of Cassia } \\
\text { angustifolia (Leguminosae) }\end{array}$ & Sennosides & Purgative \\
\hline 14 & Asafoetida & $\begin{array}{l}\text { Oleo gum resin of Ferula } \\
\text { assafoetida L. (Umbelliferae) }\end{array}$ & $\begin{array}{l}\text { Ferulic acid and } \\
\text { umbellic acid }\end{array}$ & Stimulant, carminative, expectorant \\
\hline 15 & Bael & $\begin{array}{l}\text { Unripe fruits of Aegle } \\
\text { marmelos Corr. (Rutaceae) }\end{array}$ & Marmelosin & $\begin{array}{l}\text { Digestive, appetizer, treatment of } \\
\text { diarrhea and dysentery }\end{array}$ \\
\hline 16 & Brahmi & $\begin{array}{l}\text { Herbs of Centella asiatica } \\
\text { (Umbelliferae) }\end{array}$ & $\begin{array}{l}\text { Asiaticoside and } \\
\text { madecassoside }\end{array}$ & $\begin{array}{l}\text { Nervine tonic, spasmolytic, anti- } \\
\text { anxiety }\end{array}$ \\
\hline
\end{tabular}

Using in vitro recombination, these genes can be introduced into microorganisms there by getting the desired gene products at a low cost. Genetic engineering methods provide the opportunity to increase gene expression and so affect product yield [르. It is widely believed that omega-3fatty acids are beneficial against cardiovascular disease. To-day there are sources of omega-3fatty acids available to the consumer such as some fish, flax seed and some vegetable oils. Using biotechnology it may be possible in the future to produce a vegetable oil that has ten or twenty times the amount of omega-3 fatty acids compared to present day oils. Such an oil would obviously be very useful to include in the diet of patients prone to heart disease.
Conventional plant-breeding methods can also improve nutraceutical quality and production by enhancing both agronomic and medicinal traits. In vitro propagation or tissue culture of plants holds tremendous potential for the production of high-quality plant-based medicines. This can be achieved through different methods including micro propagation and so maclonal variant production. Besides these, Nutritional genomics is a recent off-shoot of this genetic revolution in the area of nutraceutical development which includes

1.nutrigenomics: the study of interaction of dietary components with the genome and the resulting proteomic and metabolomic changes; and 
2. nutrigenetics: understanding the gene-based differences in response to dietary components and developing nutraceuticals that are most compatible with health based on individual genetic makeup $[\underline{36}, \underline{52}]$.

There are several biotechnology companies involved in investigating and developing nutraceutical products mainly belong to the food(55\%) and pharmaceutical (35\%) industries through different biotechnological approaches. Developments in plant biotechnology has created a number of results such as various new cultivars either by traditional crossing or transgenic breeding [ㅇ-82]. Super-rice that exhibits high yields has been invented by Chinese scientists, Golden Rice with high levels of the pro-vitamin A carotenoid, betacarotene, was invented and many other crops have been invented with improved agricultural and nutritional traits [83-88]. Thus advances in tissue culture, combined with improvement in genetic engineering, specifically transformation technology, cell culture methodologies for selective metabolite production, has opened new avenues for high volume production of nutraceuticals.

\subsection{Plant derived-nutraceuticals and market:}

The Nutraceutical industry is still in its formative period, and at present, there is no universal agreement or legal definitions of the terms and designations used by this industry sector. According to the widely accepted definition, "A nutraceutical is any substance that is a food or apart of a food and provides medical or health benefits including the prevention and treatment of disease." Products include isolated nutrients, dietary supplements and processed foods such as cereals, soups, soy food, and beverages [ㅇ-95].The Neutraceutical market is becoming more competitive with the entry of pharmaceutical and major food companies into the nutraceutical arena. Also, many food companies have established their Neutraceutical divisions with a view towards a diversified product line.
Pharmaceutical companies have also joined the race by acquiring dietary supplement producers. Recent years have marked the entry of major food and pharmaceutical companies into the nutraceutical marketplace, including Cargill, Hormel, GlaxoSmithKline, Heinz, Johnson \& Johnson, Kellogg, M\&M, Quaker Oats, Warner-Lambert, Unilever, and Wyeth. The nutraceuticals market is highly competitive and is driven by several factors such as price, safety, efficacy, packaging and brand loyalty, among each others [96]. The United States, Europe and Japan dominate the global market, accounting for a combined market share of more than $85 \%$. India being rich in biodiversity can come up as one of the leading countries in the production of plant based nutraceuticals. According to Frost \& Sullivan-FICCI, the Indian nutraceuticals market is expected to grow at the rate of 16 percent year onyear for the next five years [모 $\underline{9}, \underline{97-99}]$.

\subsection{Global demand of nutraceuticals:}

The nutraceutical industry lies under three main segments which include functional foods, dietary supplements, and herbal/natural products [웅. The most rapidly growing segments of the industry were dietary supplements (19.5 percent per year) and natural/herbal products (11.6 percent per year).

Regulations: A food stuff (dietary supplement) that provides health benefits, if indeed a claim was made that implied medicinal benefit regarding a nutraceutical product, the product would be required to comply with the regulatory requirements for medicinal products, in respect of safety, efficacy, and quality testing and marketing authorization procedures [ㅁ].

For decades, FDA regulated dietary supplements as foods to ensure that they were safe and wholesome and that their labelling was truthful and not misleading. 
Table 7.List of marketed nutraceutical products.

\begin{tabular}{|c|c|c|c|c|}
\hline S No. & Product & Category & Contents & Manufacturer \\
\hline 1 & Calcirol D-3 & Calcium supplement & Calcium and vitamins & $\begin{array}{l}\text { Cadilla healthcare limited, } \\
\text { Ahmedabad, India }\end{array}$ \\
\hline 2 & GRD [23-25] & Nutritional supplement & $\begin{array}{l}\text { Proteins, vitamins, minerals } \\
\text { and carbohydrates }\end{array}$ & $\begin{array}{l}\text { Zydus Cadila Ltd. } \\
\text { Ahmedabad, India }\end{array}$ \\
\hline 3 & Proteinex $®$ & Protein supplement & $\begin{array}{l}\text { Predigested proteins, vitamins, } \\
\text { minerals and carbohydrates }\end{array}$ & Pfizer Ltd., Mumbai, India \\
\hline 4 & Coral calcium & Calcium supplement & Calcium and trace minerals & $\begin{array}{l}\text { Nature's answer, } \\
\text { Hauppauge, NY, USA }\end{array}$ \\
\hline 5 & Chyawanprash & Immune booster & Amla, ashwagandha, pippali & Daburindia ltd. \\
\hline 6 & Omega woman & Immune supplement & $\begin{array}{l}\text { Antioxidants, vitamins and } \\
\text { phytochemicals (e.g. Lycopene } \\
\text { and resveratrol) }\end{array}$ & Wassen, Surrey, U.K. \\
\hline 7 & Celestial Healthtone & Immune booster & Dry fruit extract & Celestial Biolabs Limited \\
\hline 8 & Amiriprash (Gold) & $\begin{array}{l}\text { Good immune- } \\
\text { modulator }\end{array}$ & $\begin{array}{l}\text { Chyawannprash Avaleha, } \\
\text { Swarnabhasma and RasSindur }\end{array}$ & Uap Pharma Pvt. Ltd. \\
\hline
\end{tabular}

The future of nutraceuticals: Increasing awareness levels about fitness and health, spurred by media coverage are prompting the majority of people to lead healthier lifestyles, exercise more, and eat healthy. The expanding nutraceutical market indicates that end users are seeking minimally processed food with extra nutritional benefits and organoleptic value. This development, in turn, is propelling expansion in the nutraceutical markets globally. The emerging nutraceuticals industry seems destined to occupy the landscape in the new millennium. Its tremendous growth has implications for the food, pharmaceutical, healthcare, and agricultural industries Many scientists believe that enzymes represent another exciting frontier in nutraceuticals. "Enzymes have been underemployed, they're going to be a hot area in the future." Fermentation technology using microbes to create new food products also represents potential. Global trends to healthy products cannot be reversed. Companies taking the lead by investing strategically in science, product development, marketing and consumer education will not go unrewarded [ㅌ, 100-104].

Discussion: Nutritional therapy and phytotherapy have emerged as new concepts of health aid. The consumption of nutraceuticals from plant origin has become popular to improve health, prevent and treat diseases. Plant derived Nutraceuticals or functional foods have received considerable attention because of their safety and potential nutritional and therapeutic effects. Some popular phyto-nutraceuticals include glucosamine from ginseng, Omega-3 fatty acids from linseed, Epigallocatechin gallate from green tea, lycopene form tomato etc. The nutraceuticals are posses multiple therapeutic benefits though substantial evidence is lacking for the benefits as well as unwanted effects. The improvement of the dietary nutritional values of fruits, vegetables and other crops or enhancement of the bioactive components in folk herbals have become the targets of blooming plant biotechnology industry. The nutraceutical industry is growing at a rate far exceeding expansion in the food and pharmaceutical industries. The most successful nutraceutical players are likely to be those companies in which functional product are just a part of a broad line of goods satisfying both conventional and health value point. Nutraceuticals have proven health benefits and their consumption will keep diseases at bay and allow humans to maintain an overall good health. Although nutraceuticals have significant promise in the promotion of human health and disease prevention, health professional, nutritionists, and regulatory toxicologist should strategically work together to plan 
appropriate regulation to provide the ultimate health and therapeutic benefit to mankind. That is why implementation of regulatory body is necessary to standardize the nutraceutical industry. The nutraceutical industry is growing at a rate far exceeding expansion in the food and pharmaceutical industries. Herbal nutraceutical is a powerful instrument in maintaining health and to act against nutritionally induced acute and chronic diseases, thereby promoting optimal health, longevity, and quality of life. Future demand of nutraceutical depends on consumer perception of the relationship between diet and disease. Although nutraceuticals have significant promise in the promotion of human health and disease prevention, health professional, nutritionists and regulatory toxicologist should strategically work together to plan appropriate regulation to provide the ultimate health and therapeutic benefit to mankind. The clinical studies are required to scientifically validate the nutraceuticals in various medical conditions. The interaction of nutraceuticals with food and drugs is another area, which should be taken into consideration. The effect of different processing methods on the biological availability and effectiveness of nutraceuticals remains to be determined. As like drugs, there should be strict regulatory controls for nutraceuticals $[\underline{3}, \underline{5}, \underline{31}, \underline{105-}$ 107].

\section{References:}

[1] V. Brower, Nutraceuticals: poised for a healthy slice of the healthcare market? Nature biotechnology, 16 (1998) 728.

[2] G. Trottier, P.J. Boström, N. Lawrentschuk and N.E. Fleshner, Nutraceuticals and prostate cancer prevention: a current review. Nature Reviews Urology, 7 (2010) 21.

[3] A. Babaei, M. Aminikhah and A.R. Taheri, A MultiWalled Carbon Nano-Tube and Nickel Hydroxide Nano-Particle Composite-Modified Glassy Carbon Electrode as a New Sensor for the Sensitive Simultaneous Determination of Ascorbic Acid,

\section{Conclusions:}

Plant derived nutraceuticals are of great importance in present system of Medicine and Healthcare. The lack of quality control is a major area of concern for nutraceuticals. The quality of plant material and manufacturing processes used for nutraceuticals are regulated by food laws, which lack the specificity required for botanical drugs. This can have serious consequences. Nutraceutical professionals and regulatory bodies need to play a major role for safety maintenance and advances of nutraceuticals. Future demand of nutraceutical depends upon consumer perception of mankind and the relationship between diet and disease. Nutraceuticals and functional food have significant role in the promotion and care of human health to prevent diseases. Health professionals, nutritionists, biotechnologists, toxicologist and nutraceutical industrialist should strategically work together to plan appropriate regulation to provide the ultimate health and therapeutic benefits to mankind with purity, efficacy, and safety.

\section{Acknowledgements}

We sincerely appreciate the technologists at Department of Pharmaceutical chemistry, Himalayan Institute of Pharmacy Research, Dehradun for providing their facility and services for the studies.

Dopamine and Uric Acid. Sensor letters, 11 (2013) 413-422.

[4] E.K. Kalra, Nutraceutical-definition and introduction. Aaps Pharmsci, 5 (2003) 27-28.

[5] B. Chauhan, G. Kumar, N. Kalam and S.H. Ansari, Current concepts and prospects of herbal nutraceutical: A review. Journal of advanced pharmaceutical technology \& research, 4 (2013) 4.

[6] S.L. DeFelice, The nutraceutical revolution: its impact on food industry R\&D. Trends in Food Science \& Technology, 6 (1995) 59-61. 
[7] D.B. Jack, Keep takingthe tomatoes - the exciting world of nutraceuticals. Molecular medicine today, 1 (1995) 118-121.

[8] M. Mannion, Nutraceutical revolution continues at foundation for innovation in medicine conference. Am J Nat Med, 5 (1998) 30-3.

[9] R. Rishi, Nutraceuticals: borderline between food and drug. Pharma Review, (2006) 51-53.

[10] G. Hardy, Nutraceuticals and functional foods: Introduction and meaning. Nutrition (Burbank, Los Angeles County, Calif.), 16 (2000) 688.

[11] B. Esther, What is nutraceutical. Pharm. J, 265 (2000) 57-58.

[12] C. Cockbill, Food law and functional foods. British Food Journal, 96 (1994) 3-4.

[13] W.E. John, A.A. Ayi, C. Anyama, P.B. Ashishie and B.E. Inah, On the use of methylimidazolium acetate ionic liquids as solvent and stabilizer in the synthesis of cobalt nanoparticles by chemical reduction method. Advanced Journal of Chemistry-Section A, 2 (2019) 175-183.

[14] M.M. Heravi, N. Karimi and S. Pooremami, One-Pot Three Components Synthesis of 2, 4, 5-TriarylImidazoles Catalyzed by Caro's Acid-Silica Gel Under Solvent-Free Condition. Advanced Journal of Chemistry-Section A, 2 (2019) 73-78.

[15] M.H. Nasirtabrizi and S.J. Mousavi, Synthesis and chemical modification of maleic anhydride copolymers with 2-amino ethyl benzoate groups. Advanced Journal of Chemistry-Section A, 1 (2018) 56-65.

[16] J. Zhao, Nutraceuticals, nutritional therapy, phytonutrients, and phytotherapy for improvement of human health: a perspective on plant biotechnology application. Recent patents on biotechnology, 1 (2007) 75-97.

[17] C.J. Dillard and J.B. German, Phytochemicals: nutraceuticals and human health. Journal of the Science of Food and Agriculture, 80 (2000) 17441756.

[18] A.O. Adelaja and B.J. Schilling, Nutraceuticals: blurring the line between food and drugs in the twenty-first century. Choices, 14 (1999) 35-39.

[19] O.P. Gulati and P.B. Ottaway, Legislation relating to nutraceuticals in the European Union with a particular focus on botanical-sourced products. Toxicology, 221 (2006) 75-87.

[20] D.P. Richardson, Functional foods - shades of gray: an industry perspective. Nutrition Reviews, 54 (1996) S174-S185.

[21] G.S. Kasbia, Functional foods and nutraceuticals in the management of obesity. Nutrition \& Food Science, 35 (2005) 344-352.

[22] E.A. Conover, Over-the-counter products: nonprescription medications, nutraceuticals, and herbal agents. Clinical obstetrics and gynecology, 45 (2002) 89-98.

[23] M.M. Whitman, Understanding the perceived need for complementary and alternative nutraceuticals: Lifestyle issues. Clinical Journal of Oncology Nursing, 5 (2001)

[24] K.K. Adom and R.H. Liu, Antioxidant activity of grains. Journal of agricultural and food chemistry, 50 (2002) 6182-6187.

[25] C. Alasalvar, F. Shahidi and P. Quantick, Food and health applications of marine nutraceuticals: a review, in Seafoods-quality, technology and nutraceutical applications. (2002), Springer. 175204.

[26] B. Halliwell, Antioxidants in human health and disease. Annual review of nutrition, 16 (1996) 33-50.

[27] P.C. Bickford, J. Tan, R.D. Shytle, C.D. Sanberg, N. E1Badri and P.R. Sanberg, Nutraceuticals synergistically promote proliferation of human stem cells. Stem cells and development, 15 (2006) 118 123.

[28] C. Kokate, A. Gokhle and P. Khandelwal, Practical Pharmacognosy-Techniques and Experiments. Nirali Prakashan, Pune, India, Edition, 9 (2002) 149-53.

[29] S. Ross, Functional foods: the Food and Drug Administration perspective. The American journal of clinical nutrition, 71 (2000) 1735S-1738S.

[30] D. Bagchi, Nutraceuticals and functional foods regulations in the United States and around the world. Toxicology, 221 (2006) 1.

[31] M. Pandey, R.K. Verma and S.A. Saraf, Nutraceuticals: new era of medicine and health. Asian J Pharm Clin Res, 3 (2010) 11-15.

[32] V. Devi and F. Rehman, Nutraceutical Antioxidants-An over view. Indian journal of pharmaceutical education, 36 (2002) 3-8.

[33] P. Frasher, Phytosterols as functional food components and nutraceuticals. Phytochemistry, 67 (2006) 212214.

[34] E. Nordkvist, A.C. Salomonsson and P. Åman, Distribution of insoluble bound phenolic acids in barley grain. Journal of the Science of Food and Agriculture, 35 (1984) 657-661.

[35] C. Sirtori and C. Galli, Fatty acids and the Omega 3. Biomedecine and Pharmacotherapy, 56 (2002) 397-406.

[36] M.R. Subbiah, Nutrigenetics and nutraceuticals: the next wave riding on personalized medicine. Translational Research, 149 (2007) 55-61.

[37] M. Iriti and F. Faoro, Grape phytochemicals: a bouquet of old and new nutraceuticals for human health. Medical hypotheses, 67 (2006) 833-838. 
[38] Y. Shukla and M. Singh, Cancer preventive properties of ginger: a brief review. Food and chemical toxicology, 45 (2007) 683-690.

[39] A. Abdul-Hamid and Y.S. Luan, Functional properties of dietary fibre prepared from defatted rice bran. Food chemistry, 68 (2000) 15-19.

[40] V.L. Mermel, Old paths new directions: the use of functional foods in the treatment of obesity. Trends in food science \& technology, 15 (2004) 532-540.

[41] A.G. Dulloo, C. Duret, D. Rohrer, L. Girardier, N. Mensi, M. Fathi, P. Chantre and J. Vandermander, Efficacy of a green tea extract rich in catechin polyphenols and caffeine in increasing 24-h energy expenditure and fat oxidation in humans. The American Journal of Clinical Nutrition, 70 (1999) 1040-1045.

[42] S.J. Bell and G.K. Goodrick, A functional food product for the management of weight. Critical reviews in food science and nutrition, 42 (2002) 163-178.

[43] F. Brouns, Soya isoflavones: a new and promising ingredient for the health foods sector. Food Research International, 35 (2002) 187-193.

[44] M.M. Berger and A. Shenkin, Vitamins and trace elements: practical aspects of supplementation. Nutrition, 22 (2006) 952-955.

[45] C. Ramaa, A. Shirode, A. Mundada and V. Kadam, Nutraceuticals-an emerging era in the treatment and prevention of cardiovascular diseases. Current pharmaceutical biotechnology, 7 (2006) 15-23.

[46] P. Burney, G. Comstock and J. Morris, Serologic precursors of cancer: serum micronutrients and the subsequent risk of pancreatic cancer. The American journal of clinical nutrition, 49 (1989) 895-900.

[47] L.C. Clark, G.F. Combs, B.W. Turnbull, E.H. Slate, D.K. Chalker, J. Chow, L.S. Davis, R.A. Glover, G.F. Graham and E.G. Gross, Effects of selenium supplementation for cancer prevention in patients with carcinoma of the skin: a randomized controlled trial. Jama, 276 (1996) 1957-1963.

[48] Y. Toyoda, L.R. Thomson, A. Langner, N.E. Craft, K.M. Garnett, C.R. Nichols, K.M. Cheng and C.K. Dorey, Effect of dietary zeaxanthin on tissue distribution of zeaxanthin and lutein in quail. Investigative ophthalmology \& visual science, 43 (2002) 12101221.

[49] J. Weststrate and G. Meijer, Plant sterol-enriched margarines and reduction of plasma total-and LDLcholesterol concentrations in normocholesterolaemic and mildly hypercholesterolaemic subjects. European Journal of Clinical Nutrition, 52 (1998) 334.

[50] E. Block, The chemistry of garlic and onions. Sci Am, 252 (1985) 114-9.

[51] K. Pulliainen, H. Nevalainen, H. Väkeväinen, K. Jutila and C. Gummer, An analytical method for the determination of betaine (trimethylglycine) from hair. International journal of cosmetic science, 32 (2010) 135-138.

[52] A.P.B. Rabelo, E.B. Tambourgi and A. Pessoa Jr, Bromelain partitioning in two-phase aqueous systems containing PEO-PPO-PEO block copolymers. Journal of Chromatography B, 807 (2004) 61-68.

[53] P. Chen, S. Chang and H. Wu, Antimite activity of essential oils and their components from Cinnamomum osmophloeum. Quart. J. Chin. For, 35 (2002) 397-404.

[54] A. Dray, Mechanism of action of capsaicin-like molecules on sensory neurons. Life sciences, 51 (1992) 1759-1765.

[55] A. Steiber, J. Kerner and C.L. Hoppel, Carnitine: a nutritional, biosynthetic, and functional perspective. Molecular aspects of medicine, 25 (2004) 455-473.

[56] D. Vattem and K. Shetty, Biological functionality of ellagic acid: a review. Journal of food biochemistry, 29 (2005) 234-266.

[57] S. Okui, M. Uchiyama, M. Mizugaki and A. Sugawara, Intermediates of the oxidative breakdown of ricinoleic acid by Candida genus. Biochimica et biophysica acta, 70 (1963) 346-348.

[58] D. Taubert, R. Roesen, C. Lehmann, N. Jung and E. Schömig, Effects of low habitual cocoa intake on blood pressure and bioactive nitric oxide: a randomized controlled trial. Jama, 298 (2007) 4960.

[59] A.M. Anderson, M.S. Mitchell and R.S. Mohan, Isolation of curcumin from turmeric. Journal of chemical education, 77 (2000) 359.

[60] P. Mullineaux and G. Creissen. (1996), Portland Press Limited.

[61] J. Chauhan, S. Srivastava and M. Sultan, Hesperetin-7rhamnoside from Cordia obliqua [roots]. Phytochemistry, 17 (1978) 334 -335.

[62] K.H. Lee and B.M. Lee, Evaluation of the genotoxicity of (-)-hydroxycitric acid (HCA-SX) isolated from Garcinia cambogia. Journal of Toxicology and Environmental Health, Part A, 70 (2007) 388-392.

[63] H. Sakakibara, Y. Honda, S. Nakagawa, H. Ashida and K. Kanazawa, Simultaneous determination of all polyphenols in vegetables, fruits, and teas. Journal of agricultural and food chemistry, 51 (2003) 571581.

[64] F. Størmer, R. Reistad and J. Alexander, Glycyrrhizic acid in liquorice - evaluation of health hazard. Food and Chemical Toxicology, 31 (1993) 303-312.

[65] K. Prasad, Hypocholesterolemic and antiatherosclerotic effect of flax lignan complex isolated from flaxseed. Atherosclerosis, 179 (2005) 269-275.

[66] T.T. Berendschot, R.A. Goldbohm, W.A. Klopping, J. van de Kraats, J. van Norel and D. van Norren, Influence of lutein supplementation on macular pigment, assessed with two objective techniques. 
Investigative ophthalmology \& visual science, 41 (2000) 3322-3326.

[67] Y.-Y. Chang, J.-S. Liu, S.-L. Lai, H.-S. Wu and M.-Y. Lan, Cerebellar hemorrhage provoked by combined use of nattokinase and aspirin in a patient with cerebral microbleeds. Internal Medicine, 47 (2008) 467-469.

[68] A. Machowetz, H.E. Poulsen, S. Gruendel, A. Weimann, M. Fitó, J. Marrugat, R. de la Torre, J.T. Salonen, K. Nyyssonen and J. Mursu, Effect of olive oils on biomarkers of oxidative DNA stress in Northern and Southern Europeans. The FASEB Journal, 21 (2007) 45-52.

[69] R.T. Holman, The slow discovery of the importance of $\omega 3$ essential fatty acids in human health. The journal of nutrition, 128 (1998) 427S-433S.

[70] R.E. MacDonald and C.J. Bishop, Phloretin: an antibacterial substance obtained from apple leaves. Canadian Journal of Botany, 30 (1952) 486-489.

[71] M.-P. St-Onge, B. Lamarche, J.-F. Mauger and P.J. Jones, Consumption of a functional oil rich in phytosterols and medium-chain triglyceride oil improves plasma lipid profiles in men. The Journal of nutrition, 133 (2003) 1815-1820.

[72] B.D. Gehm, J.M. McAndrews, P.-Y. Chien and J.L. Jameson, Resveratrol, a polyphenolic compound found in grapes and wine, is an agonist for the estrogen receptor. Proceedings of the National Academy of Sciences, 94 (1997) 14138-14143.

[73] X. Ye, S. Al-Babili, A. Kloti and J. Zhang, Engineering the provitamin A beta-carotene biosynthetic pathway into carot. Science, 287 (2000) 5451.

[74] J. de Graaf, P.R. de Sauvage Nolting, M. van Dam, E.M. Belsey, J.J. Kastelein, P.H. Pritchard and A.F. Stalenhoef, Consumption of tall oil-derived phytosterols in a chocolate matrix significantly decreases plasma total and low-density lipoproteincholesterol levels. British Journal of Nutrition, 88 (2002) 479-488.

[75] J. Bland, Phytonutrition, phytotherapy, and phytopharmacology. Alternative Therapies in Health and Medicine, 2 (1996) 73-76.

[76] G.R. Gibson and M.B. Roberfroid, Dietary modulation of the human colonic microbiota: introducing the concept of prebiotics. The Journal of nutrition, 125 (1995) 1401-1412.

[77] M.P. Peppelenbosch and C.V. Ferreira, Immunology of pre-and probiotic supplementation. British journal of nutrition, 101 (2008) 2-4.

[78] J. Hamilton-Miller, G.R. Gibson and W. Bruck, Some insights into the derivation and early uses of the word 'probiotic'. British Journal of Nutrition, 90 (2003) 845-845.

[79] E. Ernst, Functional foods, neutraceuticals, designer foods: innocent fad or counterproductive marketing ploy? European journal of clinical pharmacology, 57 (2001) 353-355.

[80] J. Hathcock, Dietary supplements: how they are used and regulated. The Journal of nutrition, 131 (2001) $1114 \mathrm{~S}-1117 \mathrm{~S}$.

[81] W. Andlauer and P. Fürst, Nutraceuticals: a piece of history, present status and outlook. Food Research International, 35 (2002) 171-176.

[82] B. Thomas, K. Ghebremeskel, C. Lowy, M. Crawford and B. Offley-Shore, Nutrient intake of women with and without gestational diabetes with a specific focus on fatty acids. Nutrition, 22 (2006) 230-236.

[83] M.A. Grusak and D. DellaPenna, Improving the nutrient composition of plants to enhance human nutrition and health. Annual review of plant biology, 50 (1999) 133-161.

[84] S. Baima, Plant genomics ad plant breeding: at the root of human nutrition and health. Curr Top Nutraceut Res, 3 (2005) 95-112.

[85] S. Acharya, J. Thomas and S. Basu, Improvement in the medicinal and nutritional properties of fenugreek (Trigonella foenum-graecum L.). Advances in medicinal plant research, Research Signpost, Trivandrum, Kerala, India, (2007)

[86] M.A. Belem, Application of biotechnology in the product development of nutraceuticals in Canada. Trends in food science \& technology, 10 (1999) 101-106.

[87] B. Schilter, C. Andersson, R. Anton, A. Constable, J. Kleiner, J. O'Brien, A. Renwick, O. Korver, F. Smit and R. Walker, Guidance for the safety assessment of botanicals and botanical preparations for use in food and food supplements. Food and Chemical Toxicology, 41 (2003) 1625-1649.

[88] M.F. Ahmad, S.A. Ashraf, F.A. Ahmad, J.A. Ansari and M.R.A. Siddiquee, Nutraceutical market and its regulation. Am J Food Technol, 6 (2011) 342-347.

[89] R. Kroes and R. Walker, Safety issues of botanicals and botanical preparations in functional foods. Toxicology, 198 (2004) 213-220.

[90] M. Nabati, E. Lohrasbi, H. Sabahnoo, V. BodaghiNamileh, M. Mazidi, H. MohammadnejadMehrabani, A. Tavakkoli and A. Gervand, In Silico Study of Metoclopramide as A Small Molecule of Dopamine D2 Receptor: a Quantum-Mechanical (QM) Based Molecular Docking Treatment. Chemical Methodologies, 4 (2020) 19-33.

[91] I. Amar, A. Sharif, M. Ali, S. Alshareef, F. Altohami, M. Abdulqadir and M.M. Ahwidi, Removal of Methylene Blue from Aqueous Solutions using Nano-Magnetic Adsorbent Based on Zinc-Doped Cobalt Ferrite. Chemical Methodologies, 4 (2020) $1-18$.

[92] O. Ghasemi, N. Mehrdadi, M. Baghdadi and B. Aminzadeh, An investigation on absorption 
properties of exfoliated graphite for oil spill from Caspian Sea water. Iranian Chemical Communication, 7 (2019) 352-367.

[93] S.P. Patil, V.K. Mahajan, G.H. Sonawane and V.S. Shrivastava, Kinetics of photocatalytic degradation of methylene blue by $\mathrm{ZnO}$-bentonite nanocomposite. Iranian Chemical Communication, 5 (2017) $417-$ 428.

[94] P. Amudha, H. Famitha, V. Selvaraj, M. Sathiyaraj, P. Venkatesh and V. Rajendran, Propargylation of indole under a new dual-site phase-transfer catalyst: A kinetic study. Asian Journal of Green Chemistry, 2 (2018) 201-216.

[95] A.T. Adeleye, H. Louis, H.A. Temitope, M. Philip, P.I. Amos, T.O. Magu, A.U. Ozioma and O.O. Amusan, Ionic liquids (ILs): advances in biorefinery for the efficient conversion of lignocellulosic biomass. Asian Journal of Green Chemistry, 3 (2019) 391417.

[96] C.L. Taylor, Regulatory frameworks for functional foods and dietary supplements. Nutrition reviews, 62 (2004) 55-59.

[97] D. Kaushik and N. Kaushik, Nutraceuticals Regulation In India. Pharma info. net, 7 (2009) 45-46.

[98] L. Das, E. Bhaumik, U. Raychaudhuri and R. Chakraborty, Role of nutraceuticals in human health. Journal of food science and technology, 49 (2012) 173-183.

[99] P. Agarwal, S. Alok, A. Fatima and A. Verma, CURRENT SCENARIO OF HERBAL TECHNOLOGY WORLD WIDE: AN OVERVIEW. International Journal of Pharmaceutical Sciences and Research, 4 (2013) 4105.

[100] A. Taheri and S. Mohammadi, Ultrasensitive and selective non-enzymatic glucose detection based on pt electrode modified by carbon nanotubes@ graphene oxide/nickel hydroxide-Nafion hybrid composite in alkaline media. Prog. Chem. Biochem. Res., 1 (2018) 1-10.

[101] M.K. Aadesariya, V.R. Ram and P.N. Dave, Investigation of phytochemicals in methanolic leaves extracts of Abutilon pannosum and Grewia tenax by Q-TOF LC/MS. Prog. Chem. Biochem. Res., 2 (2019) 13-19.

[102] O. Solomon, W. Rabiu Saidu Umar, H. Sanusi Wara, A. Sadiq Yakubu, M. Michael Azubuike, M. Asugu Mary and H. Louis, Antiulcerogenic Activity of methanol extract and solvent fractions of Stem Bark of Lannea acida (A. Rich) Against Ethanol-Induced Gastric Mucosal Injury in Albino Rats. Prog. Chem. Biochem. Res., 1 (2019) 29-39.

[103] A.U. Itodo, O.M. Itodo, E. Iornumbe and M.O. Fayomi, Sorptive chelation of metals by inorganic functionalized organic WOx-EDA nanowires: adsorbent characterization and isotherm studies. Prog. Chem. Biochem. Res., 1 (2019) 50-59.

[104] K.K. Alisher, T.S. Khamza and Y.S. Ikbol, Quantumchemical study of geometric and energy characteristics of some bases of shiff gossipol. Prog. Chem. Biochem. Res., 2 (2019) 1-5.

[105] K. Kamari and A. Taheri, Preparation and evaluation of magnetic core-shell mesoporous molecularly imprinted polymers for selective adsorption of amitriptyline in biological samples. Journal of the Taiwan Institute of Chemical Engineers, 86 (2018) 230-239.

[106] Z.R. Zad, S.S.H. Davarani, A. Taheri and Y. Bide, A yolk shell Fe3O4@ PA-Ni@ Pd/Chitosan nanocomposite-modified carbon ionic liquid electrode as a new sensor for the sensitive determination of fluconazole in pharmaceutical preparations and biological fluids. Journal of Molecular Liquids, 253 (2018) 233-240.

[107] A. Babaei and A.R. Taheri, Direct electrochemistry and electrocatalysis of myoglobin immobilized on a novel chitosan-nickel hydroxide nanoparticlescarbon nanotubes biocomposite modified glassy carbon electrode. Anal. Bioanal. Electrochem, 4 (2012) 342-356.

\section{How to cite this manuscript:}

M. Asif and I. Mohd, Prospects of Medicinal Plants Derived Nutraceuticals: A Reemerging New Era of Medicine and Health Aid. Progress in Chemical and Biochemical Research, 2 (2019) 150-169. 